\title{
Bir Sınıf Öğretmeni ve Öğrencilerinin İlk STEM Eğitimi Deneyimleri
}

\begin{abstract}
Yasemin HACIOĞLU* Ayşe BAŞPINAR ${ }^{\dagger}$

$\ddot{O} \mathbf{z}$

Bir öğretmeninin fen, teknoloji, matematik ve mühendislik (STEM) eğitimi ile ilgili kendini geliştirmek üzere bir uzmana başvurması sonucu ortaya çıkan bu eylem araştırmasının amacı öğretmen ve öğrencilerinin süreçteki deneyimlerini paylaşarak benzer ihtiyacı olan öğretmen ve araştırmacılara örnek bir uygulama sunmaktır. Araştırmacılar öğretmenle STEM eğitimi konusunda bilgi ve deneyimler paylaşılmış ve 3. sınıf fen bilimleri dersi "Duyu Organları ve Görevleri" konusunda STEM etkinliği hazırlanmış ve uygulaması için öğretmene tanıtmıştır. Öğretmen, uzmanlar rehberliğinde, etkinliği 9 hafta boyunca 26 öğrenci ile uygulamıştır. Çalışmanın çıktılarının değerlendirilmesi için öğretmen ve öğrencilerin görüşleri alınmıştır. Öğrenci görüşleri 12 likert ve 3 açı uçlu sorudan oluşan süreç değerlendirme formu ile alınmıştır. Ayrıca her bir öğrenci için bu formdaki likert sorular öğretmen tarafından da doldurulmuştur. Likert sorular istatistiki olarak analiz edilirken, açık uçlu sorular içerik analizi ile analiz edilmiştir. Öğretmenin sürece ilişsin değerlendirmeleri için yarı yapılandırılmış görüşsme gerçekleştirilmiştir ve betimsel analiz edilmiştir. Çalışma sonunda öğretmen STEM eğitiminin uygulanması konusunda kaygılarının azaldığını, sadece öğrencilerinin değil kendisinin de süreçte eğlendiğini ve öğrencilerinin duyu organlarını öğrendiklerini belirtmiștir. Bu eylem araştırmasının öğretmenin mesleki gelişimine katkısı olduğu, öğretmen ve öğrencilerin sürece yönelik olumlu görüşleri olduğu ortaya çıkmıştır.
\end{abstract}

Anahtar Kelimeler: Duyu organları, eylem araştırması, ilkokul, STEM eğitimi

\section{A Elementary Teacher's and Students' First STEM Education Experiences}

\begin{abstract}
The aim of this action research, that arose as a result of colsulting of a elementary teacher to a specialist to self-develop on science, technology, mathematics and engineering (STEM) education, is to share the experiences of the teacher and their students and to present examples to teacher and researchers with similar needs. The researchers shared information and experiences about STEM education with the teacher, prepared a STEM activity on the subject of "Sensory Organs and Duties" and introduced to the teacher on implementation of the activity. The teachers implemented the activitiy with 26 students for 9 weeks under the guidance of the researchers. The opinions of teacher and students were taken and presented to evaluate the outcomes of the study. Students' opinions were received through a process evaluation form consisting of 12 Likert and 3 open-ended questions. In addition, likert questions in this form were filled out by the teacher for each student. While Likert questions were analyzed statistically, open-ended questions were analyzed by content analysis. A semi-structured interview was conducted for the teacher's evaluations regarding the process and descriptive analysis was conducted. She stated that while her anxiety about the implementation of STEM education decreased, the students had fun in the process and learned their sensory organs in a similar way to the students. As a result of the study, it was revealed that action research contributes to the professional development of the teacher, and the teacher and students have positive opinions about the process.
\end{abstract}

Key words: Sense organs, action research, primary school, STEM education.

Received/Geliş: 18.02.2020

Accepted/Kabul: 18.05.2020

* Bu çalışmanın etik kurul incelemesi için 28 Nisan 2020 tarihinde Giresun Üniversitesi Bilimsel Araştırma ve Yayın Etiği Kurul Başkanlığı'na başvurulmuştur. Kurulun 11.05.2020 tarihli 44079088-38 sayılı toplantısı ve 2020-3/1 sayılı kararı ile etik açıdan uygun olarak hazırlandığına karar verilmiştir.

\footnotetext{
* Sorumlu Yazar, Dr. Öğr. Üyesi, Giresun Üniversitesi Eğitim Fakültesi Matematik ve Fen Bilimleri Eğitimi Bölümü, hacioglu_yasemin@hotmail.com, (D0000-0002-1184-4204

$\dagger$ Yüksek Lisans Öğrencisi, Giresun Üniversitesi Fen Bilimleri Enstitüsü, Fen Bilgisi Eğitimi, aysebaspinar028@gmail.com, D0000-0002-1582-063X

(Makale türü: Araştırma makalesi)
} 


\section{Giriş}

Hızla değişen, gelişen bilim ve teknoloji dünyasına ayak uydurmayı bilen nesiller yetiştirmek için ülkeler çeşitli eğitim reformları gerçekleştirmişlerdir. Bu değişim içerisinde bireylerin nitelikli olması için eleştirel düşünebilen, sorgulayan, araştıran, problemleri çözebilen ve iş birliği içerisinde ürün ortaya koyabilen 21. yüzyıl becerilerine sahip olmaları gerekmektedir (Noah Harari, 2018). 21. Yüzyıl becerilerine sahip bireylerin yetiştirilebilmesi için bilginin tek bir disiplin dâhilinde verilmemesi gerekliliği daha 20. yüzyılın sonlarında fark edilmiş ve öğretimin disiplinler arası gerçekleşmesinin gerekliliği ve önemi ortaya çıkmıştır (Jacobs, 1989). Tek bir disipline ait bilgi ve becerinin gerçek yaşam problemlerinin çözümünde yetersiz kaldığ 1 gerçeği, farklı disiplinlerin bütünleştirilerek öğretiminin gerekliliğini ortaya çıkarmıştır. Disiplinler arası bakış açısı ile problem çözen ve problem çözmek için farklı disiplinlere ait kavram, bilgi ya da becerileri bir araya getiren öğrenciler öğretim programları tarafından beklenen bilgi ve becerileri de kazanacaklar; daha da ötesi bu bilgi ve becerileri farklı durumlara uyarlayabileceklerdir (Bean,1990; Jacobs, 1989).

Disiplinler arası eğitim yakın tarih bilimsel çalışmaları için önemini korurken, bilim ve teknolojideki değişim ve gelişimin hızının artması ile bazı disiplinler ön plana çıkmıştır. Örneğin Amerika Birleşik Devletleri, Çin'in gelişen teknoloji ve bilim dünyasını kendine tehdit olarak görmesi nedeniyle mühendislik ve teknoloji alanında daha çok çalışana ihtiyaç duymuştur ve bu ihtiyacı karş1lamak için bir eğitim reformu gerçekleştirmiştir (Breiner, Harkness, Johnson ve Koehler, 2012). Böylece mühendislik ve teknoloji disiplinlerinin ilgili olduğu fen ve matematik disiplinleri ile bir araya gelmesiyle disiplinler arası bir eğitim yaklaşımı olan fen (science), teknoloji (technology), mühendislik (engineering) ve matematik (mathematics) [STEM] eğitimi ortaya çıkmıştır (Bybee, 2010). Disiplinler arası entegrasyona dayanan ve 21. yüzyıl becerilerini kullanmayı gerektiren bir öğrenme-öğretme yaklaşımı (Bybee, 2010; Honey, Pearson ve Schweingruber, 2014; Riechert ve Post, 2010; United States Department of Education, 2016) olarak tanımlanan STEM eğitiminin ana amacı yenilikçi nesiller yetiştirmektir (Capraro, Capraro ve Çorlu, 2014). Bunun için tüm öğrencileri yeni yaklaşımın vizyonun bir parçası kabul ederek onlara STEM okuryazarlığı kazandırılması hedeflenmiştir (Bybee, 2013; Kennedy ve Odell, 2014). Böyle bir eğitimle öğrencilerin STEM uzmanlarının nasıl çalıştığını anlamaları gerekmektedir (Bybee, 2010). Bunu gerçekleştirmek için ise öğrencilerin STEM disiplinlerinde çalışan uzmanlar (bilim insanı, matematikçi, mühendis) gibi çalışacakları öğrenme ortamları tasarlanmalıdır (NRC, 2012). STEM okuryazarı bireyler yetiştirebilmek için öğrenme ortamı tasarımında öğrencilerin gerçek yaşam problemlerini; bilimsel ve matematiksel yöntem ve metotları kullanarak mühendislik ve teknoloji tasarım süreci uygulamalarıyla çözmesi beklenmektedir (Apedoe, Reynolds, Ellefson ve Schunn, 2008; Smith ve Karr-Kidwell, 2000). 
Böylece günlük hayattaki sorunları fark edebilen, doğal çevreyi anlayıp açıklayabilen, ilgili problemlere deliller sunmak için gerekli bilgi, tutum ve beceriye sahip olan, STEM disiplinlerinin maddi, kültürel ve entelektüel çevreyi nasıl etkilediğinin farkında olan, STEM ile ilgili konularda yapıc1 aynı zamanda yansitıcı olan ve STEM disiplinleriyle ilgilenmeye istekli bireyler yetiştirilebilir (Bybee, 2010; Kennedy ve Odell, 2014; Roberts, 2013; Stanford ve diğ., 2016).

Genel olarak STEM eğitimi var olan öğretim stratejilerinin daha fazla sorgulama ve proje tabanlı yaklaşımlarla değiştirilmesini içeriyor (Breiner ve diğ., 2012) olmasına rağmen literatürde farklı şekillerde yürütüldüğü görülebilmektedir. Bu durum bazı araştırmacıları (Bybee, 2013; Fogarty, 1991; Moore, Stohlmann, Wang, Tank ve Roehrig 2014; Ring, 2017) STEM entegrasyon ve uygulama modellerini sınıflama girişimine itmiştir. STEM entegrasyonunu içerik entegrasyonu ve bağlam entegrasyonu şeklinde sınıflandıran araştırmacılar olduğu gibi disiplinlerin ilişkisine yönelik sınıflandırma yapanlar da mevcuttur (Moore ve diğ., 2014). Bazı araştırmacılar sadece fen ve matematik disiplin entegrasyonu ile STEM eğitimi gerçekleştirilemeyeceğini, STEM yaklaşımının disiplinler arası doğasından faydalanarak teknoloji ve mühendislik entegrasyonu da gerçekleştirilmesi gerektiğini belirtmektedirler (Siew, Amir ve Chong, 2015). Bazı araştırmacılar ise bu dört disiplinin bütünleştirilmesinin zor olduğunu ve yalnızca sadece iki STEM disiplinin entegrasyonu gerçekleştiğinde STEM eğitimi gerçekleştirilebileceğini belirtmiştir (Sanders, 2009). Fogarty (1991), disiplinler arası öğretim için tek/bağımsız disiplinlerden, tam entegrasyona doğru karmaşıklaşan 10 farklı entegrasyon modeli sunmaktadır. Benzer şekilde Bybee (2013), tek disiplin referansından, bütünleşik disiplin ve transdisipliner entegrasyona doğru dokuz farklı model tanımlamış ve bu entegrasyonların birinin diğerlerine göre daha doğru olduğu savunmasının yapılmaması gerektiğini belirtmiştir. Buna karşın Karahan (2019), Bybee (2013)'nin yaptığı sınıflandırmalardan kiminde entegrasyon olmadığının eleştirilebileceğini belirtmiştir. Aynı zamanda uygulamalardaki bu farklılıkların ülkelerin eğitim sistemlerinden kaynaklanabileceğini de belirtmiştir. Farklı uygulamalar ve sınıflandırmalar STEM eğitimi gerçekleştirmeye niyetlenen araştırmacılar ve öğretmenler için de bir karmaşa olarak nitelendirilebilir.

Amerika Birleşik Devletlerinden sonra çeşitli ülkelerin STEM eğitimini gereklilik olarak görmesi ve eğitim programlarına dahil etmesinden ilk etkilenen grup hep öğretmenler olmuştur (Burrows ve Slater, 2015; Dugger, 2011; Ramaley, 2007; Williams, 2011; Williams ve diğ., 2015). Özellikle disipliner yapıda bir eğitim sistemi içerisinde disiplinler arası öğretime dayalı STEM uygulamalarının yapılması konusu durumu zorlaştırmaktadır. Bunun da ötesi sadece disiplin entegrasyonu sağlamak STEM eğitimi için yeterli değildir, öğretmenlerin öğrencileri için uygulamalı bilgi oluşturma sürecini kolaylaştırması önemlidir (Wang, 2019). STEM eğitimi 
uygulamalarında zorlanan öğretmenler gerek hizmet öncesi gerekse de hizmet içi eğitime ihtiyaç duymuşlardır (Siew ve diğ., 2015; Wang, 2012; Wang, Moore, Roehrig ve Park, 2011).

Ülkemizin de disiplinler arası yaklaşımın temel alındığı STEM eğitimine ihtiyacı olduğu gerekçesi ile Fen Bilimleri Dersi Öğretim Programı (MEB, 2018) güncellenmiştir. Öğretim programında STEM eğitimine fen, mühendislik, girişimcilik uygulamalarına ve kazanımlardan bağımsız olarak bütün üniteleri kapsayacak şekilde STEM eğitimine yer verilmeye çalışılmıştır. Bu bağlamda öğretmenlerin eğitim ihtiyacı ortaya çıkmış ve her ilde olmasa da hizmet içi eğitim çalışmalarına başlanmıştır. Fakat verilen eğitimlerin teorik, kısa süreli olması ve uygulama süreçlerinde öğretmenlere uzman desteği sağlanmaması nedenleriyle yetersiz oldukları ortaya çıkmışırı (Bozkurt Altan ve Hacıŏ̆lu, 2018). Bu durum bir öğretmenin STEM yaklaşımını sınıfında kullanmak istese de istenilen düzeyde başarı elde edemeyeceğinin bir göstergesidir (Siew, Amir ve Chong, 2015). Nitekim Bozkurt Altan ve Hacıoğlu (2018) öğretmenlerin daha çok STEM etkinlikleri hazırlama ve uygulama deneyimi kazanmaları için süreçte dönütler alarak kendilerini geliştirmeleri gerektiğini vurgulamışlar ve bu konuda uzmanlar tarafından öğretmenlere mentorlük yapılmasını önermişlerdir.

Öğretmenlerin STEM eğitimi konusunda yeterliklerini sorgulayan literatürün bir yansıması olarak bir sınıf öğretmeni (ilkokul) STEM eğitimi konusunda uzman olan birinci araştırmacıya danışmış ve kendisine mentorlük etmesi için yardım istemiştir. Birinci araştırmacı araştırma sürecini desteklemesi için STEM eğitimi konusunda deneyimli ikinci araştırmacıdan da destek alarak, destek isteyen öğretmenin onayıyla bir araştırma süreci başlatmıştır. Yapılan literatür analizinde ilkokul düzeyinde STEM etkinliklerine ihtiyacın olduğu dikkat çekmiştir. Böylece bu çalışmada araştırma sürecinde geliştirilen üçüncü sınıf öğretim programındaki 'duyu organları ve görevi’ konusunda STEM eğitimi yaklaşımına uygun etkinlik ile bu etkinliğin uygulaması ile ilgili öğrenci ve öğretmen görüşleri sunulmuştur. Burada amaç hem öğretmen ve öğrencilerinin deneyimlerini paylaşarak benzer ihtiyacı olan öğretmen ve araştırmacılara örnek sunmak hem de literatürdeki eksikliği gidermektir. Bu amaç doğrultusunda 'Duyu organları ve önemi konusunda nasıl bir STEM etkinliği geliştirilebilir ve uygulanabilir? STEM eğitimini uygulayan öğretmenin ilk deneyim sürecine yönelik görüşleri nelerdir? STEM eğitimi uygulanan ögrrencilerin STEM eğitim sürecine ilişkin değerlendirmeleri nelerdir?' sorularına cevap aranmıştır.

\section{Yöntem}

$\mathrm{Bu}$ çalışma bir sınıf öğretmeninin (ilkokul) STEM eğitimi ile ilgili kendini geliştirmek üzere bir uzmana başvurması sonucu ortaya çıkmış teknik/ bilimsel/ işbirlikçi bir eylem araştırmasıdır. Eylem araştırması var olan problemin belirlenmesi, belirlenen probleme çözümün geliştirilmesi, geliştirilen çözümün uygulanması ve değerlendirilmesi basamaklarını kapsar. 
Eylem araştırmasında hedef bilimsel bilginin öğrenilmesi ve yaşanan probleme ya da eksikliğe dair sonuçların değiştirilmesidir (Dick, 1993). Teknik/ bilimsel ve işbirliçi eylem araştırmasında ise uzman/lar rehberliğinde uygulayıcıların bir uygulamayı gerçekleştirir ve uzmanlar süreci analiz ederler (Yıldırım ve Şimşek, 2008). Bunu sağlamak için uygulanan Eylem planı Şekil 1'de özetlenmiştir.

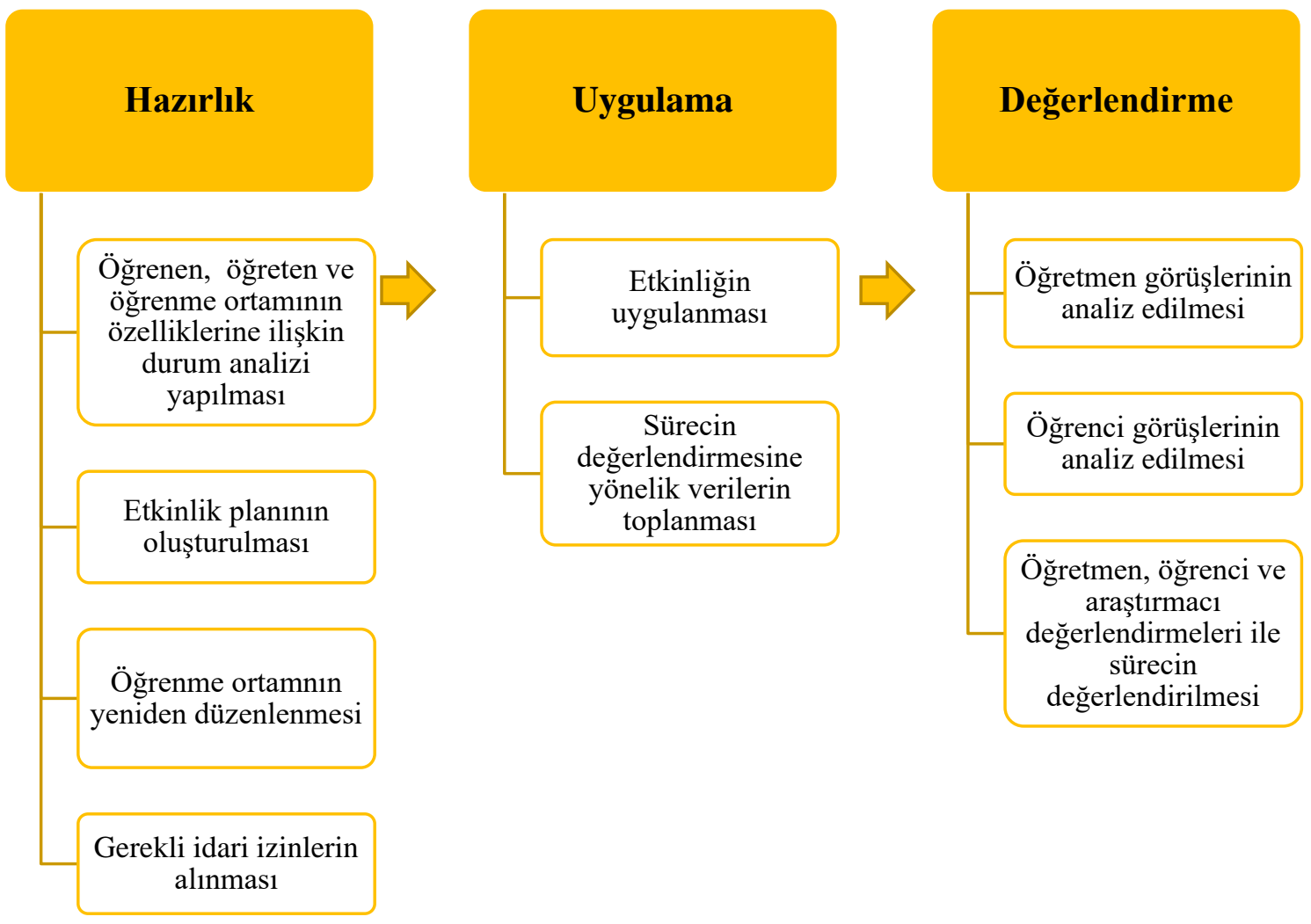

Şekil 1. Araştırmada yürütülen eylem planı

\section{Çalışma Grubu}

Araştırmanın çalışma grubunu Türkiye'nin Doğu Karadeniz'deki bir il merkezindeki, genellikle düşük ve orta sosyoekonomik düzeydeki ailelerin çocuklarının eğitim gördüğü bir devlet okulundaki bir sınıf öğretmeni ve bu öğretmenin öğrencileri olan 26 üçüncü sınıf öğrencisi oluşturmaktadır.

Öğretmenin özellikleri: STEM öğretimi konusunda daha önce hiçbir eğitim almayan ve deneyimi olmayan öğretmen 23 yıllık mesleki deneyime sahiptir. Öğretmenliğini okuttuğu sınıfın birinci sınıftan beri (üç yıldır) sınıf öğretmenidir. Öğretmen bu çalışmada araştırma sürecine sadece etkinlikleri uygulayıcı olarak katılmış, aynı zamanda kendisinden süreçle ilgili veri toplanmıştır. Öğretmen kendisi gönüllü olarak araştırmacılara danışmıştır, araştırmacılar da çalışmayı yürütmek için öğretmenden gerekli izni almışlardır.

Öğrenci özellikleri: Araştırmacılardan destek isteyen öğretmenin öğrencileri 3. sınıftır. Öğrenciler daha önce STEM eğitimi yaklaşımıyla gerçekleştirilen etkinliklere katılmamışlardır. 
Öğretmenleri ile daha önce STEM eğitimi deneyimlemeyen öğrencilerin, okul dişında da herhangi bir deneyimi olmadığı bilgisi öğretmen aracılığılla alınmıştır.

\section{Eylem süreci}

Eylem süreci hazırlık, uygulama ve değerlendirme olarak üç aşamada işletilmiştir.

Hazırlık: Uygulama öncesi birinci araştırmacı ile öğretmen arasında gerçekleştirilen toplantılarda, öğretmene (i)STEM eğitimi ve disiplin entegrasyonu ve (ii) STEM eğitimi ile ilgili örnek uygulamalar hakkında bilgi verilmiştir. Ayrıca, çalışma grubunda tanımlanan öğrenci ve öğretmenin özellikleri değerlendirilmiştir. Öğretmenin öğretim gerçekleştirdiği öğrenme ortamı araştırmacılar tarafindan okul ziyareti yapılarak değerlendirilmiştir. Öğrencilerin klasik düzen sıraları olan bir sınıf düzeni olduğu, sınıfları dışında okulun tiyatro salonu, serbest etkinlik salonu, fen bilimleri laboratuvarını da kullanabildikleri, gerekli olabilecek materyallerin öğrenciler tarafından sağlanması gerektiği görülmüştür. Öğretmenin kendini STEM eğitimi uygulamaya hazır olduğu dönemde, ilerleyen konulardan biri olan "Canlılar ve Yaşam" öğrenme alanı "Beş Duyumuz" ünitesinde yer alan "F.3.2.1. Duyu Organlarl ve Görevleri" konusunun "F.3.2.1.1. Duyu organlarının önemini fark eder. F3.2.1.2. Duyu organlarının temel görevlerini açıklar. F.3.2.1.3. Duyu organlarının sağllğını korumak için yapılması gerekenleri açıklar (MEB, 2018.)" kazanımları doğrultusunda nasıl bir etkinlik hazırlanabileceği üzerine fikir alışverişinde bulunulmuştur. Daha sonra araştırmacılar öğretmenden bağımsız çalışarak etkinlik geliştirme sürecine başlamışlardır. Öğretmenin ilk STEM öğretimi deneyimi olacă̆ göz önüne alınarak ilgili literatür (Karahan, Canbazoğlu- Bilici ve Ünal, 2015; Karahan ve Canbazoğlu Bilici, 2014) gözden geçirilerek öğrencilerin hem mühendislik tasarım sürecini (Kafai, 2005) hem de bilimsel araştırma sürecini işe koşabileceği kamu spotu tasarımı görevi çerçevesinde STEM entegrasyonu sağlayabileceği sonucuna varılmıştır. Böylece Moore ve diğ. (2014)'nin açıkladığı fen ve matematik bilgi ve becerisinin uygulaması olarak mühendislik tasarım sürecini işe koşarak teknoloji üretmek ya da geliştirmektir olan STEM eğitimi yaklaşımı benimsenmiştir. Bu yaklaşımla öğretmenin fen eğitimine mühendislik/ teknoloji entegre etmenin ve öğrencilerden beklenen bilgi/ becerilerin kazandırılmasının bir yolu olarak mühendislik tasarım etkinliklerinden yararlanma konusunda deneyim kazanabileceği öngörülmüştür (Householder ve Hailey, 2012; Lemons, Carberry, Swan ve Rogers, 2010; Moore, Tank, Glancy, Kersten ve Stohlmann, 2013; NRC, 2012).

Öğretim programında (MEB, 2018) konunun altı ders saatinde işlenmesi önerilmektedir. Fakat bu çalışmada disiplinler arası entegrasyonun sağlanması ve öğretmen/ öğrencilerin STEM öğretimi konusunda deneyimsiz olmaları nedeniyle uygulama sürecine haftalık ders programında yer alan Serbest Etkinlikler Dersi de dahil edilerek toplam dokuz ders saatlik (3 hafta) bir etkinlik tasarlanmıştır. Araştırmacılar tarafından, öğrencilerin; duyu organlarını tanımalarını ve 
birbirleriyle olan temel ilişkileri kavramalarını, duyu organlarının sağlığını korumak için yapılması gerekenlere yönelik bilgi ve becerileri kazanmaları amacıyla STEM eğitimine yönelik bir etkinlik planı hazırlanmıştır. Grup çalışması şeklinde uygulanması planlanan etkinlikte ilk olarak öğrencilere her bir duyu organının işlevi ile ilgili bir kız çocuğunun günlük yaşamından örnekler verilmiştir. Bu örnek olay ile öğrencilerin dikkati duyu organlarına toplandıktan sonra duyu organlarının önemi, görevi ve sağlı̆̆ı ile ilgili özellikleri (kriter ve sınırlıkları) belirtilen bir tasarım görevi verilmiştir. Süreçte hem mühendislik tasarım sürecini hem de araştırma sorgulama sürecini işletebilmeleri için yönergeler sunulmuştur. Tasarım görevini gerçekleştirmek için bilgiye ihtiyaçları olduğuna ve araştırma yapmalarına ilişkin yönergeler sunulmuştur. Öğrenciler araştırmalarını yaptıktan sonra tasarım görevinin özelliklerini karşılayacak kamu spotu senaryolarını oluşturmaları istenmiştir. Senaryoları oluşturduktan sonra tasarımı gerçekleştirmeleri, değerlendirmeleri, gerekirse iyileştirmeleri ve son olarak da sınıfta sunmaları istenmiştir. Etkinlik uygulama aşamasında ayrıntılı olarak açıklanmıştır.

Hazırlanan etkinlik için öncelikle STEM eğitim uzmanı görüşüne başvurulmuştur. Uzman görüşleri doğrultusunda düzenlendikten sonra, uygulayıcı olan öğretmenden etkinliğin öğrenci düzeyine uygunluğu ve öğrencilerin mevcut öğrenme ortamında uygulanabilirliği konusunda görüş alınmıştır. Uzman ve öğretmen görüşleri doğrultusunda etkinlik revize edilmiş ve etkinlik föyünün son hali verilmiştir.

Etkinlik, fen bilimleri ve serbest etkinlikler derslerinde yürütülmek üzere planlanmıştır. Öğrenme ortamı STEM eğitimi gerçekleştirmek üzere uygulama öncesi yeniden düzenlenmiştir. Etkinliğin gerçekleştirilmesi için gerekli materyaller (el kamerası, projeksiyon gibi) öğretmenin de desteği ile araştırmacılar tarafından hazırlanmıştır. Öğrencilerin kamu spotu senaryolarında kullanabilecekleri çeşitli kıyafet veya malzemeleri kendileri getirmeleri planlanmış, eğer öğrenciler temin edemezse öğretmen ve araştırmacılar tarafından temin edilmesi kararlaştırılmıştır. Öğretmen tarafından beş ve altı öğrenciden oluşan beş heterojen (daha önceden gözlenmiş olan başarıya göre) grup oluşturulmuştur. Öğrenci sıraları birleştirilerek grup çalışmasına uygun hale getirilmiştir. Hazırlanan ve uygulamanın gerçekleştiği öğrenme ortamlarından (sınıf, kütüphane, tiyatro salonu) görüntüler Şekil 2'de verilmiştir.
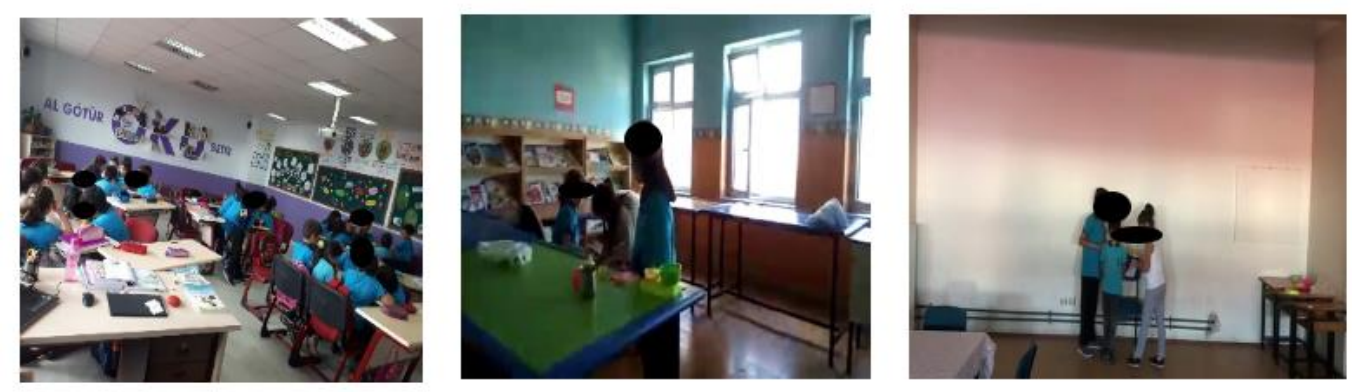

Şekil 2. Öğrenme ortamlarından görüntüler 
Eylem sürecinin değerlendirilmesine ilişkin veri toplama araçları hazırlanmıştır. Veri toplama araçlarından biri olan alan notları alması ve araştırma kapsamında etkinliğin uygulanmas1, süreç boyunca öğretmene rehberlik etmek için ikinci araştırmacının sınıfta bulunması, sadece araştırmada kullanılmak üzere ses ve görüntü kaydı alınması konusunda okul yönetimi bilgilendirilmiş ve onayları alınmıştır. Öğrenciler ve velileri süreçten haberdar edilmiştir. Ayrıca öğrenci velilerinden öğrencilerinin öğretmenleri gözetiminde araştırma sürecine dahil olması için öğretmen aracılığı ile izin alınmıştır. Araştırmada katılımcıların bilgi ve onayı dahilinde veri (yazılı görüş, ses ve video kaydı) toplanmıştır ve kullanılmıştır.

Uygulama: Bu uygulama grup çalışması şeklinde 3. sınıf öğrencileri (n=26, 14 kız, 12 erkek) ile dokuz ders saati boyunca Giresun ilindeki bir devlet okulunda gerçekleştirilmiştir. Uygulamayı öğretmen gerçekleştirmiştir. İkinci araştırmacı eylem planının işleyebilmesi için süreç boyunca gözlem yapmış, birinci araştırmacı ile süreci değerlendirerek öğretmene destek olmuştur.

Uygulama başlangıcında etkinlik föyü öğrencilere dağıtılmış ve ders yönergeler doğrultusunda öğretmen tarafindan yürütülmüştür.

Öğrencilere sürecin nasıl işletilmesi gerektiği öğretmen tarafından ifade edilmiştir. Hazırlanan etkinlik föyündeki soru ve yönergelerle yürütülmesi kolaylaştırılmıştır. Süreçte öğretmen öğrencilere rehber olmuştur. Uygulama sürecinde aşağıda belirtilen derslerde ve sürelerde açıklanan adımlar takip edilmiştir.

Fen Bilimleri Dersi (40 dakika): İlk aşamada öğrenci gruplarına etkinlik föyü dağıtılmıştır. Duyu organlarının işlevine yönelik Ceyda adlı bir kız çocuğunun duyu organlarının işlevine yönelik günlük yaşamından bir kesit içeren örnek olay verilerek, 'Ceyda güneşin sıcaklığını hangi organı ile hissetmiştir? Ceyda mutfaktan gelen kokuları hangi organı ile almıştır? Ceyda sütün lezzetini hangi organı ile almıştır? Ceyda birbirini kovalayan köpekleri, etrafında dolaşan kedileri hangi organı ile fark etmiştir? Ceyda'nın kuş seslerini hangi organıyla duymuştur? Ceyda sütün lezzetini hangi duyu organıyla almıştır?' şeklinde her bir duyu organının işlevine yönelik sorular sorulmuştur. Eğer duyu organları işlevini kaybetseydi neler olurdu?' soruları sorulmuştur. Bu aşamada bu organların duyu organları olarak ifade edildiği öğretmen tarafından belirtilmesi beklenir. Daha sonra bu organların önemine dikkat çekmek için 'Ĕger Ceyda'nın bu organları işlevini kaybetseydi neler olurdu?' sorusu sorulmuştur. Sonrasında öğrencilere duyu organlarının önemini ve sağlı̆̆ını korumak için neler yapılması gerektiğini anlatan kamu spotu oluşturma tasarım görevi verilmiştir. Tasarım görevinde kriter ve sinırlılıklar belirtilmiştir: Kamu spotunun 'en az ü̧̧ duyu organı ile ilgili bilgiler içermesi, en az 3 en fazla 5 dakikalık olması, dikkat çekici olması ve kamu spotunda kendileri rol oynamaları ve çekmeleri' gerektiği belirtilmiştir. Bu aşamada öğrencilerin kamu spotunun ne olduğunu bilmemeleri göz 
önünde bulundurularak öğrencilere örnek kamu spotu örnekleri gösterilmiştir. Ardından öğrencilerden tasarlamaları istenen kamu spotunun özelliklerini belirtmeleri istenmiştir.

Tasarım görevi tanımlanırken tasarım görevini gerçekleştirebilmek için bilimsel bilgiye ihtiyaç duyulacağı 'Kamu spotunun bu özelliklerini gerçekleştirmek için neleri bilmeniz gerekiyor?' sorusu ile öğrencilere fark ettirilmiştir. Öğrencilere bu görevin gerçekleştirilebilmesi için gruplar olarak bilimsel araştırma yapmaya ihtiyaç duydukları öğretmen tarafindan belirtilmiştir. İlerleyen derslerde sırasıyla tüm duyu organları ile ilgili araştırma sorgulama süreci işe koşularak, kamu spotunda yer alacak ilgili duyu organı ile ilgili senaryoyu oluşturmaları sağlanmıştır.

Fen Bilimleri Dersi (40 dakika x 3) - Serbest Etkinlik Dersi (40 dakikax 2): Öncelikle fen bilimleri dersinde görme duyu organı olan gözün işlevi, önemi ve sağlığı konusunda öğretmen tarafından sınıfa yöneltilen 'Gözün işlevi ve önemi nedir? Gözümüzün sağllğını korumak için neler yapmalıyzz?' şeklinde sorular ve devamında gelen tartışmalarla öğrencilerin görme organının işlevi, önemi ve sağlı̆̆ını öğrenmeleri sağlanmıştır. Sonrasında serbest etkinlikler dersinde 'Gözümüzün önemini anlatan ve gözümüzün sağglığını korumak için neler yapılması gerektiğini anlatan senaryo yazınız. ' yönergesi verilmiştir. Öğrenciler grup arkadaşlarıyla beraber gözün önemi ve sağlığının korunmasına yönelik kamu spotlarında kullanacakları senaryolarını yazmışlardır. $\mathrm{Bu}$ işlem benzer şekilde kulak, burun, deri ve dil duyu organları için tekrar edilmiştir. Öğrenci senaryolarından örnekler Şekil 3’te sunulmuştur.

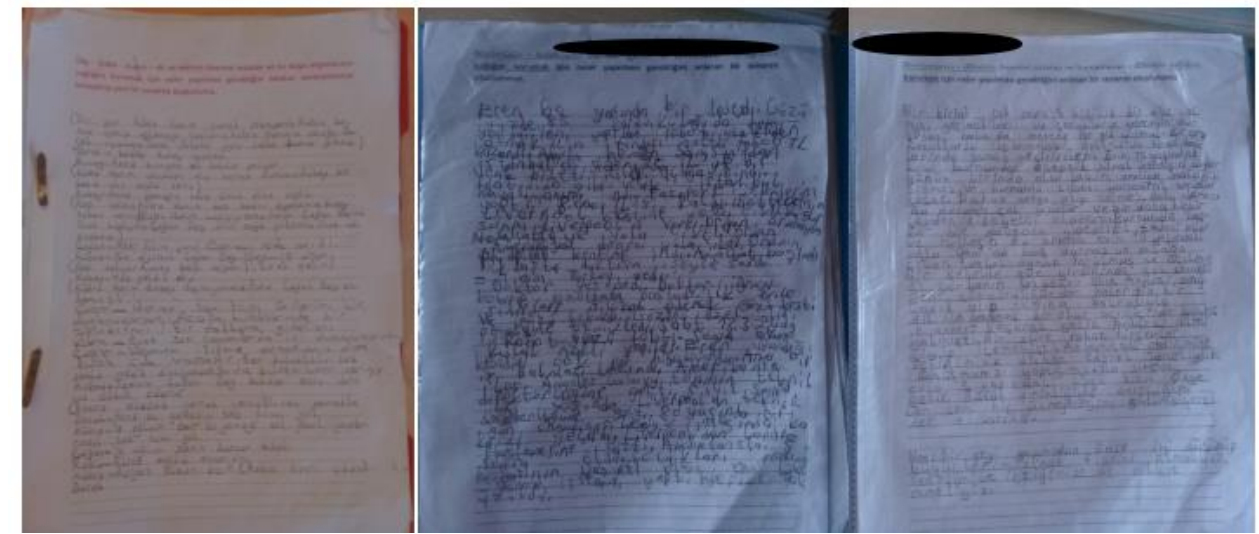

Şekil 3. Öğrencilerin yazdığı kamu spotu senaryolarından örnekler

Serbest Etkinlik Dersi (40 dakika): Daha önceki toplam 4 ders saatinde öğrenciler tüm duyu organları ile ilgili beklenen kazanım içeriğindeki bilgileri edinip, her bir duyu organına yönelik kamu spotunda kullanacakları senaryoları ayrı ayrı yazmışlardır. Bu derste ise, tasarım görevinde verilen ve öğrencilerin ilk derste tanımladıkları kamu spotlarının özelliklerini dikkate alarak bu senaryolarını birleştirme/kısaltma/ekleme işlemleriyle yaparak yeniden düzenlemişlerdir. $\mathrm{Bu}$ süreçte öğretmen öğrencilere rehberlik etmiştir. Ardından grup üyeleri 
arasında rol dağılımı yapan öğrenciler, senaryolarına uygun kıyafetlerini, gerekli malzeme ve materyallerini belirlemişlerdir.

Fen Bilimleri Dersi (40 dakika): Bu ders için öğrenciler senaryolarını oynayabilmek için gerekli kıyafet ve materyalleri temin etmiş ve yanlarında getirmişlerdir. Öğrenciler, araştırmacılar ve öğretmen tarafından temin edilen kameralarla onların rehberliğinde ve yardımıyla kamu spotu için senaryolarını oynama ve kameraya çekme işlemini gerçekleştirerek kamu spotlarını oluşturmuşlardır. Öğrenciler bir ders saati içerisinde çekimlerini gerçekleştirip, istenen özelliklere göre değerlendirmişlerdir. Bu süre içerisinde yeniden çekim yapmak veya kayıtlarını düzenlemek isteyen gruplar kamu spotlarını revize edebilmiştir. Öğrenciler çekim yapmak için okulun çeşitli salonları ve sınıflarını kullanabilmişlerdir. Öğrencilerin kamu spotu sahnelerinden görüntüler Şekil 4'te sunulmuştur.
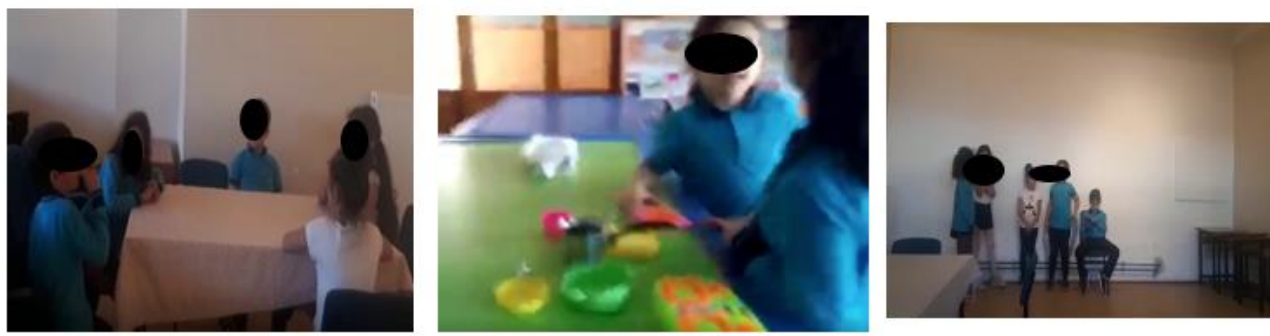

Şekil 4. Öğrencilerin kamu spotu videolarından görüntüler

Fen Bilimleri Dersi (40 dakika): Her grup kendi kamu spotunu, karşıladıkları özellikleri belirterek sunmuştur. $\mathrm{Bu}$ süreçte kullandıkları bilgileri ve ne şekilde kullandıklarını, hangi bilgilere neden yer vermediklerine ilişkin açıklamalarda bulunmaları (Örneğin; neden sadece göz, kulak ya da dil duyu organlarını diğerlerine tercih ettiklerini belirtmeleri istenmiştir) ve kamu spotlarında iyileştirme yapmaları gerekse neleri düzelteceklerini belirterek öz değerlendirme yapmaları sağlanmıştır. Diğer grupların ise sunulan kamu spotunun istenen özelliklerini ne düzeyde gerçekleştirebildiklerini ifade ederek akranlarını değerlendirmeleri sağlanmıştır. Öğretmen tarafından öğrencilere yöneltilen sorularla duyu organları hakkında neler öğrendiklerine dair geri bildirimler alınmıştır. Grupların kamu spotlarını tanıttıkları sunum sürecine ilişkin görüntüler Şekil 5’te sunulmuştur.
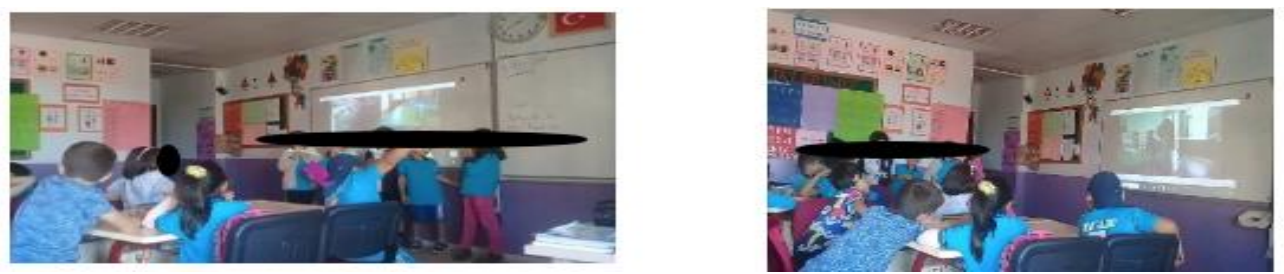

Şekil 5. Öğrencilerin kamu spotlarını sunma sürecine ilişkin görüntüler

Değerlendirme-Veri toplama Araçları ve Analizi: Eylem sürecinin değerlendirmesi öğretmen ve öğrenci değerlendirilmesine ilişkin veri toplama araçları ile sağlanmıştır. 
Araştırmada öğrencilerin etkinliğe yönelik görüşlerini belirlemek için "Öğrenci Değerlendirme Anketi” kullanılmışırı. Bu anket hazırlanırken ilk olarak Schnitka ve Richards (2008) tarafindan oluşturulmuş ve daha sonra Bozkurt Altan ve Karahan (2019) tarafindan uyarlanmış bir anketten faydalanılmıştır. Bunun için belirtilen anketten ilkokul öğrencilerine uyarlanarak hazırlanan 12 likert tipi ve 3 açık uçlu soru kullanılmıştır. Ayrıca anketin öğrencilere uygunluğu konusunda öğretmenden görüş alınmıştır. Ankette etkinliğin eğlenceli ya da zor olması, süreçten hoşlanma durumları, öğrendiklerini günlük yaşamla ilişkisi duyu organlarının önemi, temel görevleri ve sağılığını ne kadar öğrendiklerine yönelik görüşleriyle ilgili likert tipi sorular yer almaktadır. Bu sorular sürecin sonunda hem öğrenciler tarafindan hem de her öğrenci için ayrı ayrı olmak üzere öğretmen tarafindan doldurulmuştur. Ankette yer alan likert tipi maddelerin ( 1 ile 10 arası derecelendirme) her biri için ortalama değer hesaplanmıştır. Ankette ayrıca öğrencilerin etkinliği en iyi ve kötü yönü ile değerlendirmeleri ve etkinlikte öğrenmeleri amaçlanan kazanımların neler olduğuna ilişkin üç açık uçlu soru yer almaktadır. Bu sorular ise sadece öğrenciler tarafından doldurulmuş ve içerik analizi ile çözümlenmiştir.

Ayrıca hem eylem sürecinde uygulayıcı hem de sürecin bir öğesi olan öğretmenle de uygulama sonunda yarı yapılandırılmış görüşmeler gerçekleştirilmiştir. Öğretmene öncelikle ilk STEM eğitimine deneyimine ilişkin görüşleri sorulmuştur. Ardından sürecin öğrencilere etkisi üzerine dört soru yönlendirilmiştir. Görüşme 13 dakika sürmüştür. Elde edilen bu öğrencilere ilişkin değerlendirmeler ve öğretmenin STEM eğitimi deneyimine ilişkin iki temada betimsel analiz ile analiz edilmiştir. Öğretmenin öğrencilere ilişkin değerlendirmeleri, öğrencilerden elde edilen verilerin içerik analizi ile değerlendirilmesi ile oluşan kodlar ve temalar çerçevesinde çözümlenmiştir.

Araştırma verileri öncelikle araştırmacılardan biri tarafından gerçekleştirilmiştir, daha sonra uygun kategorileştirme yapılıp yapılmadığ 1 konusunda ikinci araştırmacı tarafından kontrol edilmiştir. İki araştırmacı arasında görüş birliği sağlanarak bulgular oluşturulmuştur. Öğretmen ve öğrenci görüşlerinden doğrudan alıntılar verilmiştir.

\section{Bulgular}

Araştırma kapsamında öğrencilerin kendi görüşleri ve öğretmenin değerlendirmelerine ilişkin Öğrenci Değerlendirme Anketinden elde edilen bulgular Şekil 6'da sunulmuştur. 


\section{Öğrenci değerlendirmeleri}

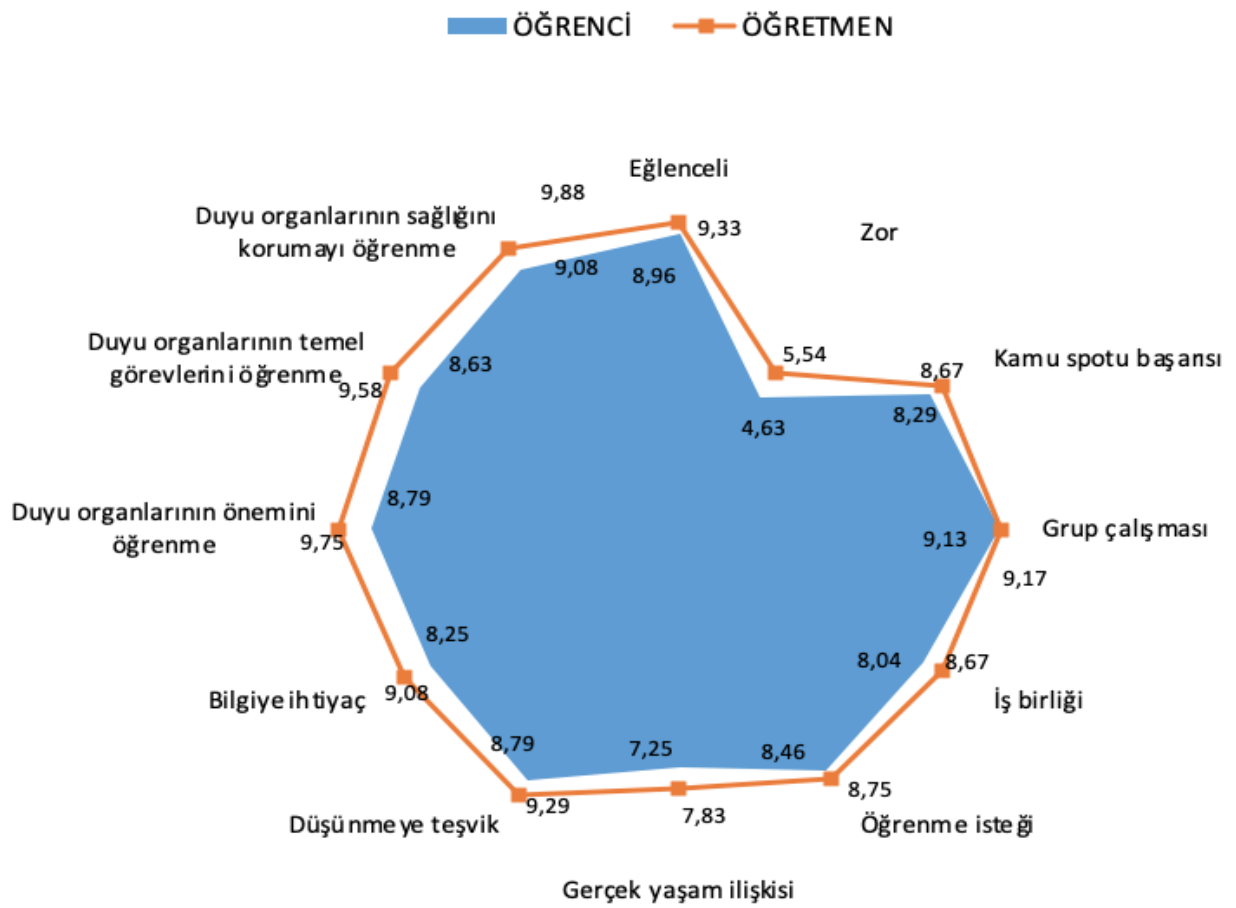

Şekil 6. Öğrencilerin kendi görüşleri ve öğretmenin değerlendirmelerine ilişkin bulgular Şekil 6'da görüldüğg̈ gibi öğrenciler süreç boyunca zorlansalar da süreci olumlu yönde değerlendirmişlerdir. Ayrıca öğrencilerin süreçle ilgili değerlendirmeleri, öğretmenlerinin onlar için yaptıkları değerlendirmeler ile benzerlik göstermektedir. Hatta öğretmenin öğrencilere yönelik yaptığı değerlendirmeleri, öğrencilerin değerlendirmelerinden daha olumlu olduğu dikkat çekmektedir. Öğrenciler en çok sürecin eğlenceli olması ve grup çalışmasına ilişkin olumlu görüş bildirirken, öğretmen öğrencilerin en çok duyu organlarının sağlığını, temel görevlerini ve önemini öğrenmesi konusunda olumlu görüş belirtmiştir. Öğrenci öğrenmelerine ilişkin öz değerlendirmeleri ile ilgili derinlemesine bilgi almak için öğrencilere 'Kamu spotu tasarım sürecinde neler öğrendiniz?' sorusu sorulmuş ve öğrenci cevaplarına ilişkin bulgular Tablo 1'de sunulmuştur.

Tablo 1. Öğrencilerin süreçten öğrendiklerine ilişkin öz değerlendirmeleri

\begin{tabular}{|c|c|c|c|}
\hline Tema & Kod & $\mathbf{n}$ & Öğrenci görüșlerinden örnek \\
\hline \multirow{10}{*}{ Konu İçeriği } & Göz /görme & 5 & \multirow{10}{*}{$\begin{array}{l}\text { Ö10 (E) "Duyu organlarımızın göz, kulak, dil, burun ve deri } \\
\text { olduğunu ve bunların sağllğın nasıl koruyacağımızı } \\
\text { ögrendik." } \\
\text { Ö3(K): "Burun, göz, kulak, dil, deri olan duyu organlarımızl, } \\
\text { onları korumak için neler yapabileceğimizi ...ögrendim." }\end{array}$} \\
\hline & Burun / koku & 4 & \\
\hline & Kulak/ işitme & 4 & \\
\hline & Dil / tat alma & 6 & \\
\hline & Deri / dokunma & 3 & \\
\hline & Duyu organlarının neler olduğu & 7 & \\
\hline & Duyu organlarının görevleri & 2 & \\
\hline & Duyu organlarının önemi & 14 & \\
\hline & Duyu organlarının sağlı̆̆1 & 9 & \\
\hline & Birlikte çalışma / grup çalışması & 5 & \\
\hline
\end{tabular}




\begin{tabular}{|c|c|c|c|}
\hline Tema & Kod & $\mathbf{n}$ & Öğrenci görüșlerinden örnek \\
\hline \multirow{2}{*}{$\begin{array}{l}\text { İş birliği } \\
\text { içerisinde } \\
\text { çalışma }\end{array}$} & Yardımlaşma / dayanışma & 7 & \multirow{2}{*}{$\begin{array}{l}\text { Ö11(E): "Dayanışma ve yardımlaşmayı öğrendim. Böyle işleri } \\
\text { küçümsememeyi ögrendim." }\end{array}$} \\
\hline & Görev paylaşma & 2 & \\
\hline \multirow{4}{*}{$\begin{array}{l}\text { Tasarım } \\
\text { yapma }\end{array}$} & Kamu spotu hazırlama & 2 & \multirow{4}{*}{$\begin{array}{l}\text { Ö14 (E): “... Başka bir zaman sahneye çıkarsam heyecanımı } \\
\text { yenmeyi ögrendim, güzel bir sunum yapabilirim." }\end{array}$} \\
\hline & Senaryo yazma & 1 & \\
\hline & Rol oynama / drama & 1 & \\
\hline & Çekim yapma & 1 & \\
\hline
\end{tabular}

Tablo 1'de görüldüğü gibi öğrencilerin öğrenmelerine ilişkin değerlendirmelerinde daha çok konu içeriğine değindikleri, bununla birlikte iş birliği ve tasarım becerilerinin gelişimine yönelik görüşler sundukları görülmektedir.

Öğretmenle gerçekleştirilen görüşmede öğrencilerin görüşlerini destekler nitelikte sürecin katkısını da içeren “...̈̈ğrenciler öğrenmeyi hedeflediğimiz kazanımlara ulaştılar. Yaptığımız değerlendirme sonuçlarından bunu görebildim...” şeklinde açıklamalarda bulunmuştur.

Öğrenci öğrenmesine ilişkin araştırmacı notlarında ise öğrencilerin duyu organları konusunda kazandıkları bilgilerini kamu spotu tasarımlarına aktarabildiklerini, kamu spotlarını sunma aşamalarında bu bilgileri ifade ettikleri yer almaktadır.

Öğrencilerin sürece yönelik olumlu görüşlerini belirlemek amacıyla 'Kamu spotu tasarım sürecinde en kolayınıza giden/ en hoşunuza gitmeyen/ olumlu durum neydi?' sorusu sorulmuştur. Öğrenci cevaplarından elde edilen verilere ilişkin bulgular Tablo 2'de sunulmuştur.

Tablo 2. Öğrencilerin sürece yönelik olumlu değerlendirmelerine ilişkin bulgular

\begin{tabular}{|c|c|c|c|}
\hline Tema & Kod & $\mathbf{n}$ & Öğrenci görüşlerinden örnek \\
\hline \multirow{6}{*}{$\begin{array}{l}\text { Tasarım } \\
\text { süreci }\end{array}$} & Senaryo yazma & 5 & \multirow{6}{*}{$\begin{array}{l}\text { Ö17 (K): "Senaryoda görme engelli kişinin kitabı } \\
\text { okuması vardl. Ben de kabartma kitabı ilk kez gördüm } \\
\text { ve buna şaşırdım. Onların yaşadıklarını hissettim." }\end{array}$} \\
\hline & Görev dağılımı & 2 & \\
\hline & Rol oynama/canlandırma & 5 & \\
\hline & Prova yapma & 5 & \\
\hline & Çekim yapma & 6 & \\
\hline & Eğlenme & 8 & \\
\hline \multirow[t]{3}{*}{ Öğrenme } & Konuyu öğrenme & 2 & \multirow{3}{*}{$\begin{array}{l}\text { Ö8 (E): "Önemli bilgiler edindik ve bu bilgileri } \\
\text { kullanarak bir kamu spotu hazırladık. Benim çok } \\
\text { yaratıcı ve rolümü çok iyi oynamamdı." }\end{array}$} \\
\hline & Eğlenerek öğrenme & 5 & \\
\hline & Yaparak yaşayarak öğrenme & 8 & \\
\hline \multirow{3}{*}{$\begin{array}{l}\text { Beceri } \\
\text { kazanma }\end{array}$} & Grup çalışması & 4 & \multirow{3}{*}{$\begin{array}{l}\text { Ö1(K): “... hep birlikte hepimizin kararlarını alıp, } \\
\text { değerlendirip çalışmak en iyi yanıydı." }\end{array}$} \\
\hline & Eleştirel düşünme & 1 & \\
\hline & Karar verme & 1 & \\
\hline \multirow{5}{*}{$\begin{array}{l}\text { Kişisel } \\
\text { farkındalık }\end{array}$} & Yaratıcilık & 1 & \multirow{5}{*}{$\begin{array}{l}\text { - Ö9 (E): "İleride yönetmen olursam, film çekerken bize } \\
\text { - yardımci olur." }\end{array}$} \\
\hline & Rol yapma yeteneği & 1 & \\
\hline & Kariyer farkındalığ & 1 & \\
\hline & Öğrendiğinin farkına varma & 1 & \\
\hline & Engelli farkındalığı/empati kurma & 4 & \\
\hline Hepsi iyi & & 3 & $\begin{array}{l}\text { Ö14 (E): "Ben hepsinde çok eğlenmiştim. Gösteriyi } \\
\text { çekmek çok hoşuma gitti. Grupta herkes eğlenebildi. } \\
\text { Zekileşmiş ve ögrenmiş olduk." }\end{array}$ \\
\hline
\end{tabular}


Tablo 2'de görüldüğü üzere öğrencilerin sürece yönelik olumlu değerlendirmelerine ilişkin daha çok tasarım sürecine değindikleri, bununla birlikte öğrenmeye, beceri kazanmaya ve kişisel farkındalığına yönelik görüş bildirdikleri görülmektedir.

Öğretmen ile yapılan görüşmede öğrencilerin görüşlerini destekler nitelikte sürece yönelik öğrencilerin olumlu değerlendirmeleri yer almıştır. Öğretmen, öğrencilerinin tasarım sürecinde aktif ve üretici oldukları, yaparak yaşayarak öğrenmeye vurgu yaparak süreçten keyif aldıklarını belirtmiştir: "Derse kendileri katıldıkları ve bir ürün koyarak oluşturabildikleri için uygulama daha keyifli ve daha ögretici oldu. Sürecin çocuklar üzerinde olumlu etkileri oldu...”. Öğrencilerin öz değerlendirmelerine ilişkin “...Hatta bir daha böyle bir uygulama yaparsak daha iyi bir ürün ortaya koyabilirim, daha iyi performans sergileyebilirim gibi geri bildirimlerde bulundular..." şeklinde görüş bildirmiştir.

Bununla birlikte öğretmen, öğrencilerin konuyu öğrenmelerine ilişkin “...Öğrencilerin konuyu öğrendiklerini düşünüyorum... Çocuklar da süreçte eğlendiklerini fazlasıyla söyledi. Çünkü kendileri ortaya ürün koyuyor ve öğreniyorlardı. Öğrenirken eğleniyorlardl..." görüşü ile öğrenci görüşlerine benzer şekilde eğlenerek öğrenmeye, iş_birliği ve grup çalışmasının etkisine ilişkin sıklıkla vurgu yapmıştır:

“...Öğrenciler öğrenmeyi hedeflediğimiz kazanımlara ulaştılar. Yaptığımız değerlendirme sonuçlarından bunu görebildim... Öğrenciler sıkılmadan ĕglenerek öğrenebiliyorlar ortaya kendi ürünlerini iş birliği ve dayanışma içerisinde ortaya koyuyorlar. Bu da onlar için kalıcı öğrenmeyi sağllyor ... Öğrencilere özgür bir alan bırakıldĭğ için bu alanda kendilerini daha rahat ifade edebiliyorlar. Bilimsel bilgiye ulaşıp ulaştıkları bilgiyi ürüne grup çalışmasıyla dönüştürebiliyorlar...”.

Öğrencilerin sürece yönelik olumsuz görüşlerini belirlemek amacıyla 'Kamu spotu tasarım sürecinde en zorlandığınız/ en hoşunuza gitmeyen/ olumsuz durum neydi?' sorusu sorulmuştur. Öğrenci cevaplarından elde edilen verilere ilişkin bulgular Tablo 3'te sunulmuştur.

Tablo 3. Öğrencilerin sürece yönelik olumsuz değerlendirmelerine ilişkin bulgular

\begin{tabular}{|c|c|c|c|}
\hline Tema & Kod & $\mathbf{n}$ & Öğrenci görüşlerinden örnek \\
\hline \multirow[t]{6}{*}{ Tasarım süreci } & Senaryo oluşturma & 2 & \multirow{6}{*}{$\begin{array}{l}\text { - Ö17(K): "Görev paylaşımı yapmak ve senaryoyu yapmak } \\
\text { - çok mu çok zordu." }\end{array}$} \\
\hline & $\begin{array}{l}\text { Araştırdıklarını/öğrendiklerini } \\
\text { tasarıma aktarma }\end{array}$ & 1 & \\
\hline & Rol dağılımı & 5 & \\
\hline & Rol oynama & 9 & \\
\hline & Çekim yapma & 5 & \\
\hline & Replikleri ezberleme & 4 & \\
\hline \multirow{3}{*}{$\begin{array}{l}\text { İş birliği } \\
\text { içerisinde } \\
\text { çalışmak }\end{array}$} & $\begin{array}{l}\text { Bazı arkadaşlarla birlikte } \\
\text { çalışma }\end{array}$ & 4 & \multirow{3}{*}{ Ö5(K): “... adlı arkadaşımla birlikte çalışmak zordu."” } \\
\hline & Grup çalışması yapmak & 4 & \\
\hline & $\begin{array}{l}\text { Bazı kişilerin sorumluluklarını } \\
\text { yerine getirmemesi }\end{array}$ & 1 & \\
\hline \multicolumn{2}{|c|}{ Motivasyon düşüşü } & 1 & $\begin{array}{l}\text { Ö12 (E): “...çekim yaparken zorlandiğım için yapma } \\
\text { isteğim azaldı." }\end{array}$ \\
\hline \multicolumn{2}{|c|}{ Sürecin kötü yanı yok } & 3 & \\
\hline
\end{tabular}


Tablo 3’te görüldüğü üzere öğrencilerin sürece yönelik olumsuz değerlendirmelerine ilişkin daha çok tasarım sürecine değindikleri görülmektedir. Bununla birlikte öğrenciler iş birliği içerisinde çalışmanın da zor olduğunu belirttikleri görülmektedir. Öğrenciler genellikle tasarım süreci açısından en çok rol oynamaya, iş birliği açısından bazı arkadaşlarla birlikte çalışma ve grup çalışması yapmaya yönelik olumsuz görüş belirtmelerine karşın süreci olumsuz değerlendirmeyen üç öğrenci olduğu dikkat çekmektedir. Bu bulguyu destekler nitelikte öğretmen de öğrencilerinin böylesi bir sürece alışkın olmamaları ve daha önce STEM eğitimi ile ilgili deneyimleri olmamasına rağmen süreç ilerlediğinde sürece yönelik olumlu tutum sergilediklerini, öğrencilerden olumsuz tepki almadığını ifade etmiştir:

“...Başlangıçta çocuklar uygulamayı yadırgadılar ama sürece adapte olmaları uzun sürmedi. Çocuklar uygulamayı eğlenceli buldukları için bu anlamda uygulama süreci iyi geçti... Hiçbir öğrencimden olumsuz bir tepki almadım. Hatta bugün kamu spotu yapalım gibi isteklerde bulundular. Sadece bir öğrencimin velisi bana çocuğunun bu uygulamadan dolayı okula gelmek istemediğini belirtti. Sonrasında ben ögrencimin kamu spotu hazırlama etkinliğinde aldı̆̆ rolü

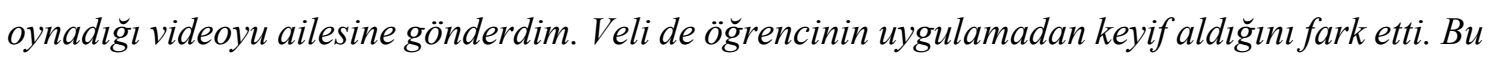
ögrencim de bir daha yapılsa kendime daha fazla güvenerek daha iyi bir ürün ortaya koyabilirim geri bildiriminde bulundu. Bunun dışında olumsuz bir durum gözlemlemedim..."

Öğrencilerin sürece ilişkin görüşleri ve öğretmenin öğrenciler açısından süreci değerlendirmeleri dışında, uygulayıcı olarak sürece ilişkin görüşler de sunduğu dikkat çekmektedir. Öğretmen uygulanan STEM etkinlik sürecinde fen öğrenme için araştırma sorgulama yapmanın önemine ve etkisine vurgu yapmıştır:

"Tasarım görevinin sürecin başında verilmesi ögrrencileri bu görevi gerçekleştirmek için bilgiye ihtiyaç hissettirmiştir. Bu amaca ulaşmak için araştırmalarını yaptıkları ve aşama aşama senaryolarını oluşturmaları öğrenmelerine katkı sağlamakla birlikte araştırma yapma becerilerine de katkı sağlamıştır. Bilgilerini hemen tasarımlarında uygulama imkanları oldu. Çekimlerini beklediğimden daha kısa sürede gerçekleştirdiler. Böyle olmasaydı sürekli beğenmeyip, tekrar tekrar çekmek isteyecekler ve zaman kaybı olacaktı..."

Öğretmen süreçle ilgili genelde olumlu görüşler sunmasının yanında uygulama sürecinde süre kullanımı ile ilgili kaygı yaşadığını da belirtmiş̧tir: “... Uygulamanın benim için tek olumsuz yanı zamandı diyebilirim başka bir olumsuzlukla karşılaşmadım. Zamanla ilgili yetişecek mi diye sürekli kaygı yaşadım. Ama süreç sandı̆̆ımdan iyi ilerledi. Bir dahaki uygulamada daha iyi yapabileceğimi düşünüyorum..."

Aynı zamanda öğretmen daha önce böylesi bir deneyimi olmadığı için tedirginliklerini ve süreçte nasıl üstesinden geldiğini “...Başlangıçta ilk defa kullanmamdan dolayı sınıf yönetimini 
ve disiplini uygulama sürecine yapabilme konusunda tedirgin olmuştum. Ancak şaşırtıcı bir şekilde normal zamandan daha iyi oldu." ifadeleri ile belirtmiştir. Ayrıca öğretmenin

“...Süreçte sizlerin desteği ve paylaşımları da tüm kaygılarımın anlamsız olduğunu göstermiştir. Bu iş birliği olmasaydı STEM eğitiminin temellerini yanlı̧̧ anlamış olacaktım. Ben sadece ögrencilere ne yaptırabilirim diye araştırlyordum. Sadece materyal geliştirmem yeterli olacak diye düşünüyordum. Bir de biz ders anlatmaya eğilimliyiz ya, sanki ben önce konuyu anlatacağım, sonra da bu bilgilere yönelik materyal tasarımı yaptıracaktım. Size yönlendirildiğim de önce bunların farkina vardım. Siz de hem hazırlık sürecimizde hem de uygulama sürecimizde bu konuda uyarılarda bulunuyordunuz zaten. Ben de gerçekten ögrenci merkezli çalışma nasıl olur deneyimlemiş oldum. Sonuçlarının olumlu olması da beni motive etti..." şeklindeki açıklaması öğretmen-akademik iş birliği önemine dikkat çektiği görülmektedir. Bu açıklama ile eylem araştırmasının önemine de vurgu yapıldığı söylenebilir.

\section{Sonuç ve Tartışma}

Eylem araştırması olarak yürütülen bu araştırmada bir sınıf öğretmeninin ihtiyacı doğrultusunda, alanında uzman araştırmacılar tarafından fen bilimleri dersi için duyu organları konusunu içeren STEM eğitim yaklaşımına yönelik etkinlik planı geliştirilmiştir. Giresun ili devlet okulunda ki 3. sınıf öğrencilerine araştırmacılar eşliğinde daha önce STEM eğitimi yaklaşımı hakkında bilgi ve tecrübesi olmayan sınıf öğretmeni tarafından uygulanmış ve değerlendirilmiştir.

Uygulama süreci sonunda hem öğrencilerin hem de öğretmenin, öğrenmenin gerçekleştiğine yönelik değerlendirmelerde bulunmaları STEM eğitiminin fen öğrenme üzerinde etkisinin bir göstergesidir. Öğrencilerin süreçte öğrendiklerinin neler olduğunu belirtmeleri de bu durumu destekler niteliktedir. Bunlarla birlikte öğretmenin uygulama sürecinde kamu spotlarının sunum aşamasında yapılan biçimlendirici değerlendirilmenin yanında, sonuç odaklı yapılan değerlendirme sınavında da fen bilimleri dersi için üstün performans gösterdiklerini belirtmesi STEM eğitiminin öğrenci başarısını arttırmada etkili olduğu şeklinde değerlendirilebilir. Öğretmen bu durumu öğrencilerin süreçte eğlenmelerinin yanında sürecin gerçek yaşamla ilişkili olması, öğrencilerin süreçte aktif olmalarının gerekliliği, düşünmeye ve bilgiye ihtiyaç duymaları ve öğrenme isteklerinin artması ile bu ihtiyaçlarını karşılamak için araştırma yapmaları ile açıklamıştır. Nitekim ilgili alan yazın da STEM eğitiminin öğrencilerin süreçte aktif olması ile tutum ve motivasyonlarına olumlu etkisi olduğu belirtilmektedir (Brophy, Klein, Portsmore ve Rogers, 2008; Gülhan ve Şahin, 2016; Yamak, Bulut ve Dündar, 2014). Ancak öğretmenin de belirttiği gibi STEM eğitiminin bilimsel araştırma sorgulamadan uzak gerçekleştirildiğinde beklenen hedeflere ulaşılamayacağ ${ }_{1}$ (Karahan, 2014; Moore ve diğ., 2010) ve el becerilerinin geliştirmenin ötesine geçemeyeceği (Bozkurt Altan ve Karahan, 2019) de bir gerçek olarak 
karşımıza çıkmaktadır. STEM eğitiminde doğru entegrasyonun sağlanması ve uygulanmasıyla öğrenci öğrenmesi gerçekleşmekte ve başarısı arttırmaktadır (Apedoe, Reynolds, Ellefson ve Schunn 2008; Ercan ve Şahin, 2014; Fortus ve diğ., 2004; İnce, Misır, Küpeli ve Frrat, 2018; Mehalik ve diğ., 2008; Sadler, Coyle ve Schwartz, 2000; Silk, Schunn ve Cary, 2009).

Öğrenciler ve öğretmen, öğrencilerin tasarım sürecinde başarılı olduğunu belirtmiş olsalar da sürece yönelik öğrencilerin olumsuz değerlendirmeleri tasarımı oluşturma üzerinedir. Öğrenciler özellikle rol oynamakta zorlandıklarını belirtmişlerdir. Bunun için öğretmenlere okul öncesinden itibaren daha çok dramatik araştırma sorgulamanın yer aldığı STEM etkinlikleri deneyimlerini öğrenme ortamına getirmeleri önerilebilir (Malone ve diğ., 2018). Ayrıca öğrenciler süreçte senaryolarının çekimi sırasında zorlandıklarını belirtmişlerdir. Öğretmen bu durumu senaryolarını oynarken tek çekim yaptıkları için tekrar tekrar baştan çekmeleri gerektiği ile açıklamıştır. Bu çalışmanın bir eylem araştırması olması nedeniyle öğretmenin ve öğrencilerin teknolojik uygulamaları konusunda yeterlilikleri ve öğrenme ortamları ve fiziki koşulları dikkate alınarak teknoloji entegrasyonu fen ve mühendislik entegrasyonuna göre arka planda tutulmuştur. Fakat gerekli şartlar sağlandığında kamu spotunu çeşitli teknoloji uygulamaları ile gerçekleştirebilirlerdi (Baran, Canbazoğlu Bilici ve Mesutoğlu, 2015). Böylece hem teknoloji bilgileri ve okuryazarlıklarının gelişmesine katkı sağlanabilir, hem de süre, öğrencilerin sürece uyumu gibi sorunların üstesinden gelinebileceği düşünülmektedir. $\mathrm{Bu}$ durum örnek STEM uygulamalarının farklı öğrenme ortamlarına uyarlanarak yürütülebileceğini göstermektedir.

Öğrenciler ve öğretmen, ilk defa STEM eğitim yaklaşımıyla ders yürütüldüğü için uygulama sürecinin başında zorlandıklarını fakat süreçte eğlendiklerini belirtmişlerdir. Öğrencilerin çoğu grup çalışmasında başarılı olduklarını söylemelerine rağmen, bazı öğrenciler sürecin en zor yanının grup çalışması olmasından ve iş birliği yapmanın zorluğundan bahsetmiştir. Kimi öğrenci de süreçte iş birliği içerisinde çalışmayı öğrenmiş olmayı sürecin olumlu yanı olarak ifade etmiştir. Öğretmen görüşleri de öğrencilerin grup çalışması ve iş birliği içerisinde çalışmalarının onların iletişim becerileri ile birlikte sorumluluk bilincini ve özgüvenlerinin artmasını sağladığı yönündedir. İlgili literatür dikkate alındığında (Niess, 2005) bu durum STEM eğitiminin öğrencilerin iletişim, iş birliği ve grup çalışması becerilerine etkisinin olumlu olduğu şeklinde yorumlanabilir. Öğretmenin, kendi uyarıları nedeniyle öğrencilerin grupları içerisinde iş birliği olmasına rağmen gruplar arasındaki etkileşimin az olmasını belirtmesi dikkate alınması gereken bir durumdur. Bunun için süreçte her bir tasarım süreci aşamasında öğrencilerin uygulamalarını ve deneyimlerini sınıf arkadaşlarına sunmalarına fırsat verilmesi önerilebilir. Grup içi çalışmalarda ise bazı öğrencilerin kendi fikirlerini grup arkadaşlarına kabul ettirmede 1srarcı olmaları, sonrasında da grup içerisinde ortak fikir ve karara varabilmeleri eleştirel düşünme ve karar verme sürecine girdiklerinin göstergesidir. Nitekim tasarım destekli 
aktiviteler öğrencilerin eleştirel düşünme ve karar verme becerilerinin gelişmesine ortam hazırlamaktadır (Ercan, 2014; Ure, 2012). Bununla birlikte öğrenci ve öğretmen değerlendirmeleri genel olarak ele alındığında STEM eğitiminin öğrenenlerin problem çözme ve yaratıcılık gibi 21. yy becerilerinin gelişimine katk1 sağladığı söylenebilir.

Öğretmen STEM eğitimi yaklaşımına yönelik etkinliğin uygulama sürecinde, sadece süre kullanımı kaygısı sorununu olduğunu belirtmiştir. Siew ve diğ. (2015) da yaptıkları araştırmada STEM eğitimi yaklaşımıyla gerçekleştirilen etkinliklerin zaman aldığını belirtmişlerdir. Öğretmenlerle ile yürütülmüş olan farklı çalışmalarda da STEM eğitimi uygulamaları konusunda onları engelleyen en büyük kaygı süre kullanımıdır (Bozkurt, 2014; Hacığglu, Yamak ve Kavak, 2016, 2017). Fakat öğretim programlarında kazanımlar için önerilen süreler esnetilebileceği gibi, STEM eğitiminin disiplinler arası doğası işe koşulduğunda ilişkili disiplin dersinde süre kullanımı sınırlılı̆̆ının üstesinden gelinebilir. Ayrıca uygulama süreçlerinde deneyim kazandıkça bu sorunun da ortadan kalktığı görülebilir.

Araştırmalar STEM eğitimi için en önemli gerekliliğin öğrencilerin öğrenmesine disiplinler arası bir yaklaşım ve çağdaş öğrenme ortamlarının öğrenme sürecine dahil edilmesi olduğunu ifade etmektedir (Bouwma-Gearhart, Perry ve Presley, 2014). Fakat bu araştırmanın da ortaya çıkmasını sağlayan etkenlerden biri olan, öğretmenlerin hem disiplinler arası hem de çağdaş bir yaklaşım olan STEM eğitimi uygulamaya ilişkin endişe ve kaygılarının olmasıdır. Öğretmenlerin kaygıların başında, bu araştırmanın sonuçlarında da yer alan zaman yönetimi ve pedagojik alan bilgisi açısından hissettikleri yetersizlik gelmektedir (Hacıoğlu, Yamak, Kavak, 2016; 2017). Bu çalışmalar araştırmanın sonuçları ile birlikte değerlendirildiğinde STEM eğitiminin uygun öğrenme ortamları hazırlandığında ve öğretmenlere mentor olunduğunda uygulanabileceğinin göstergesidir. Böylece hem öğrenme ortamındaki fiziksel şartlara yönelik kaygıların azaldığı hem de öğretmenin öğretme denetimine ilişkin kaygıların azalabileceğinin göstergesidir.

$\mathrm{Bu}$ çalışmanın bir eylem araştırması olması nedeniyle ilgili eylem planı çerçevesinde bir ilk okul öğretmeni ve onların sürece ilişkin değerlendirmeleri ile sınırlıdır. Etkinlik farklı araştırmacı ya da öğretmenler tarafından farklı gruplara uygulanabilir. Bununla birlikte uygulanan etkinliğinin çıktılarının farklı ölçme araçları ile (başarı testi, beceri testi, tutum testi gibi) ölçülüp, sonuçları sunulabilir. Bunun da ötesi öğretmen ve öğrenci arasındaki bilimsel iletişim, öğrencilerin tasarım sürecindeki grup tartışmaları ve konuşmaları incelenerek kavramsal öğrenmeleri, bilimsel dili kullanabilme durumları incelenebilir (Wang, 2019). 


\section{Kaynakça}

Apedoe, X. S., Reynolds, B., Ellefson, M. R. \& Schunn, C. D. (2008). Bringing engineering design into high school science classrooms: The heating/cooling unit. Journal of Science Education and Technology, 17(5), 454-465.

Baran, E., Canbazoğlu Bilici, S. \& Mesutoğlu, C. (2015). Fen, teknoloji, mühendislik ve matematik (FeTeMM) spotu geliştirme etkinliği. Araştırma Temelli Etkinlik Dergisi, $5(2), 60-69$.

Bean, J. P. (1990). Why students leave: Insights from research. In D. Hossler, (Ed), The Strategic Management of College Enrollments: Chapters 9 and 10. San Francisco: Josey-Bass.

Bouwma-Gearhart, J., Perry, K.H. \& Presley, J.B. (2014). Improving postsecondary STEM education: Strategies for successful interdisciplinary collaborations and brokering engagement with education research and theory. Journal of College Science Teaching, 44(1), 40-47.

Bozkurt, E. (2014). Mühendislik tasarım temelli fen eğitiminin fen bilgisi öğretmen adaylarının karar verme becerisi, bilimsel süreç becerileri ve sürece yönelik algılarına etkisi. Yayımlanmamış doktora tezi, Gazi Üniversitesi Eğitim Bilimleri Enstitüsü, Ankara.

Bozkurt Altan, E. \& Hacıŏglu, Y. (2018). Fen bilimleri öğretmenlerinin derslerinde STEM odaklı etkinlikler gerçekleştirmek üzere geliştirdikleri problem durumlarının incelenmesi. Necatibey Ĕgitim Fakültesi Elektronik Fen ve Matematik Ĕgitimi Dergisi, 12(2), 487-50.

Bozkurt Altan, E. \& Karahan, E. (2019). Tasarım temelli fen eğitimine yönelik öğrenci ve öğretmen değerlendirmeleri: Isı yalıtımı ülke kazanımı etkinliği. İlköğretim Online, 18 (3): s.1345-1366. http://ilkogretim-online.org.tr doi:10.17051/ilkonline.2019.612575

Breiner, J. M., Harkness, S. S., Johnson, C. C. \& Koehler, C. M. (2012). What is STEM? A discussion about conceptions of STEM in education and partnerships. School Science and Mathematics, 112(1), 3-11.

Brophy, S., Klein, S., Portsmore, M. \& Rogers, C. (2008). Advancing engineering education in P-12 classrooms. Journal of Engineering Education, 97(3), 369-387.

Burrows, A. \& Slater, T. (2015). A proposed integrated STEM framework for contemporary teacher preparation. Teacher Education and Practice, 28(2/3), 318-330.

Bybee, R. W. (2010). What is STEM education? Science, 329(5995), 996. doi: 10.1126/science. 1194998 .

Bybee, R. W. (2013). The case for STEM education: Challenges and opportunities. Arlington, Virginia: National Science Teachers Association.

Capraro, M. Capraro, R. \& Çorlu M. (2014). Introducing STEM education: Implications for educating our teachers for the age of innovation. Eğitim ve Bilim, 39(171), 74-85. 
Dick, B. (1993). Action research theses. Retrieved from http://www.aral.com.au/DLitt/DLitt_P50arth.pdf

Dugger, W. E. (2011). Evolution of STEM in The United States. Retrieved from http://www.iteaconnect.org/Resources/PressRoom/AustraliaPaper.pdf.

Ercan, S. \& Şahin, F. (2015). Fen eğitiminde mühendislik uygulamalarının kullanımı: Tasarım temelli fen eğitiminin öğrencilerin akademik başarıları üzerine etkisi. Necatibey Eğitim Fakültesi Elektronik Fen ve Matematik Eğitimi Dergisi, 9(1), 128-164.

Fogarty, R. (1991). Ten ways to integrate the curriculum. Educational Leadership, 49(2), 61-65.

Fortus, D., Dershimer, R.C., Krajcik, J., Marx, R.W \& Mamlok-Naaman, R. (2004). Design-based science and student learning. Journal of Research in Science Teaching, 41(10), 10811110 .

Gülhan, F. \& Şahin, F. (2016). Fen-teknoloji-mühendislik-matematik entegrasyonunun (STEM) 5. sınıf öğrencilerinin bu alanlarla ilgili algı ve tutumlarına etkisi. International Journal of Human Sciences, 13(1), 602-620. doi:10.14687/ijhs. v13i1.3447

Hacıŏlu, Y., Yamak, H. \& Kavak, N. (2016). Mühendislik tasarım temelli fen eğitimi ile ilgili öğretmen görüşleri. Bartın Üniversitesi Eğitim Fakültesi Dergisi, 5(3), 807-830., Doi: 10.14686/buefad. v5i3.5000195411

Hacioğlu, Y., Yamak, H. \& Kavak, N. (2017). The opinions of prospective science teachers regarding STEM education: The engineering design based science education. Gazi Üniversitesi Gazi Ĕ̆itim Fakültesi Dergisi, 37(2), 649-684.

Householder, D. L. \& Hailey, C. E. (2012). Incorporating Engineering Design Challenges into $\begin{array}{llll}\text { STEM Courses. } & \text { Retrieved }\end{array}$ https://digitalcommons.usu.edu/cgi/viewcontent.cgi?article=1164\&context=ncete_publi cations

Honey, M., Pearson G. \& Schweingruber, H. (2014). STEM integration in K-12 education: status, prospects and an agenda for research. Washington: The National Academic Press.

İnce, K., Mısır, M. E., Küpeli, M. A. \& Fırat, A. (2018). 5. sınıf fen bilimleri dersi yer kabuğunun gizemi ünitesinin öğretiminde STEM temelli yaklaşımın öğrencilerin problem çözme becerisi ve akademik başarısına etkisinin incelenmesi.Journal of STEAM Education, 1(1), 64-78.

Jacobs, H. H. (1989). Design options for an integrated curriculum, H.H. Jacobs (Ed). Interdisciplinary curriculum: Design and implementation. Alexandria, VA: Association for Supervision and Curriculum Development. 
Kafai, Y. B. (2005). The classroom as living laboratory: design-based research for understanding, comparing, and evaluating learning science through design. Educational Technology, 45(1), 28-34.

Karahan, E. \& Canbazoğlu Bilici, S. (2014). Fen, Teknoloji, Mühendislik ve Matematik (FeTeMM) Ĕgitimi. Ö., Keleş (Editör), Uygulamalı Etkinliklerle Fen Eğitiminde Yeni Yaklaşımlar içinde. (s.77-96). Ankara: Pegem Akademi.

Karahan, E., Canbazoglu Bilici, S. \& Ünal, A. (2015). Integration of media design processes in science, technology, engineering, and mathematics (STEM) education. Eurasian Journal of Educational Research, 60, 221-240.

Karahan, E. (2019). STEM eğitim yaklaşımı. A. G. Balım (Editör), Fen öğretiminde yenilikçi yaklaşımlar içinde (s.171-186). Ankara: Anı.

Kennedy T \& Odell M (2014). Engaging students in STEM education. Science Education International, 25(3), 246-258.

Lemons, G., Carberry, A., Swan, C., Jarvin, L. \& Rogers, C. (2010). The benefits of model building in teaching engineering design. Design Studies, 31(3), 288-309.

Malone, K. M., Tiarani, V., Irving. K. E., Kajfez, R., Lin, H., Giasi, T. \& Edmiston, B. W. (2018). Engineering design challenges in early childhood education: Effects on student cognition and interest. European Journal of STEM Education, 3(3), 11.

Millı̂ Eğitim Bakanlığı (2018). Fen Bilimleri Dersi Öğretim Programı (İlkokul ve Ortaokul 3, 4, 5, 6, 7 ve 8. Sinıflar) Öğretim Programı. Ankara: Devlet Kitapları.

Mehalik, M., Doppelt, Y. \& Schunn, C. D. (2008). Middle school science through design based learning versus scripted inquiry: better overall science concept learning and equity gap reduction. Journal of Engineering Education, 97(1), 71-85.

Moore, T. J. \& Glancy, A. W. \& Tank, K. M. \& Kersten, J. A. \& Stohlmann, M. S. \& Ntow, F. D. \& Smith, K. A. (2013). A Framework for Implementing Quality K-12 Engineering Education Paper presented at 2013 ASEE Annual Conference \& Exposition, Atlanta, Georgia. Retrieved from https://peer.asee.org/19060

Moore, T. J., Stohlmann, M. S., Wang, H. H., Tank, K. M., Glancy, A. W. \& Roehrig, G. H. (2014). Implementation and integration of engineering in K-12 STEM education. In Engineering in pre-college settings: Synthesizing research, policy, and practices (p. 35-60). Purdue University Press.

Niess, M. L. (2005). Preparing teachers to teach science and mathematics with technology: Developing a technology pedagogical content knowledge. Teaching and Teacher Education, 21(5), 509-523.

Noah Harari Y. (2018). 21. Yüzyll 21 Ders. İstanbul: Kolektif Kitap. 
National Research Council [NRC]. (2012). A Framework for k-12 science education: practices, crosscutting concepts, and core ideas. Washington DC: The National Academic Press.

Ramaley, J. A. (2007). Facilitating change: Experience with the reform of STEM Education. Retrieved from http://www.wmich.edu/science/facilitatingchange/Products/RamaleyPresentation.pdf

Riechert, S. E. \& Post, B. K. (2010). From Skeletons To Bridges \& Other, STEM enrichment exercises for high school biology. The American Biology Teacher, 72(1), 20-22. Doi: 10.1525/abt.2010.72.1.6

Roberts, A. (2013). STEM is here. Now what? Technology and Engineering Teacher, 73(1), 2227.

Sanders, M. (2009). STEM, STEM education, STEMmania. The Technology Teacher, 68(4), 2026.

Sadler, P. M., Coyle, H. P. \& Schwartz, M. (2000). Engineering competitions in the middle school classroom: Key elements in developing effective design challenges. The Journal of the Learning Sciences, 9(3), 299-327.

Schnittka, C. \& Richards, L. (2008). Teacher and student feedback about engineering design in middle school science classrooms: A pilot study. Pittsburgh, Pennsylvania: Annual Conference \& Exposition. Retrieved from https://peer.asee.org/3340

Siew, N., Amir, N. \& Chong, C. (2015). The perceptions of pre-service and in-service teachers regarding a project-based stem approach to teaching science. Retrieved from https://www.ncbi.nlm.nih.gov/pmc/articles/PMC4320214/

Silk, E. M., Schunn, C. D. \& Cary, M. S. (2009). The impact of an engineering design curriculum on science reasoning in an urban setting. Journal of Science Education and Technology, 18(3), 209-223.

Smith, J. \& Karr-Kidwell, P. (2000). The interdisciplinary curriculum: a literary review and a manual for administrators and teachers. Retrieved from ERIC database. (ED443172).

Stanford, C., Cole, R., Froyd, J., Friedrichsen, D., Khatri, R. \& Henderson, C. (2016). Supporting sustained adoption of education innovations: The designing for sustained adoption assessment instrument. International Journal of STEM Education, 3(1), 1-13.

United States Department of Education. (2016). STEM 2026: A vision for innovation in STEM education. Washington, DC: US Department of Education, Office of Innovation and Improvement.

Ure, H. (2012). The effect of the engineering design process on the critical thinking skills of high school students. (Unpublisched master dissertation). Brigham Young University: Utah. Retrieved from http://scholarsarchive.byu.edu/etd/3089 
Wang, H. (2012). A New era of science education: science teachers 'perceptions and classroom practices of science, technology, engineering, and mathematics (STEM) integration. (Doctoral dissertation). Retrieved from https://conservancy.umn.edu/handle/11299/120980

Wang, H. H. (2019). Examining patterns in teacher-student classroom conversations during stem lessons. Journal for STEM Education Resesearch. Retrieved from https://doi.org/10.1007/s41979-019-00022-x

Wang, H. H., Moore, T. J., Roehrig, G. H. \& Park, M. S. (2011). STEM integration: Teacher perceptions and practice. Journal of Pre-College Engineering Education Research, 1(2), 2.

Williams, J. (2011). STEM education: Proceed with cautions. Design and Technology Education: an International Journal, 16(1), 26-35. Retrieved from https://ojs.lboro.ac.uk/DATE/article/view/1590/1514

Williams, C., Walter, E., Henderson, C. \& Beach, A. (2015). Describing undergraduate STEM teaching practices: A comparison of instructor self-report instruments. International Journal of STEM Education, 2(1), 1-14.

Yamak, H., Bulut, N. \& Dündar, S. (2014). 5. Sınıf öğrencilerinin bilimsel süreç becerileri ile fene karşı tutumlarına FeTeMM etkinliklerinin etkisi. Gazi Eğitim Fakültesi Dergisi, 34(2), 249- 265.

Yıldırım, A. ve Şimşek, H. (2008). Sosyal bilimlerde nitel araştırma yöntemleri. (7. Baskı). Ankara: Seçkin Yayıncılık. 